\title{
TEACHERS' PERCEPTION OF PUNISHMENT AS CONTROL METHODS FOR SECONDARY SCHOOL STUDENT IN OREDO LOCAL GOVERNMENT AREA OF EDO STATE
}

\author{
Ehiaghe FA*1, Ehiaghe IJ2, Osakue E3, Aladenika S3, Iyen, R.I.2, Osakue O4
}

1. Department of Hematology, College of Health Sciences, Igbinedion University, Okada. Nigeria.

2. Lahor Research and medical centre, 121, Old Benin -Agbor Road, Benin City, Nigeria.

3. Department of Pathology, Igbinedion University Teaching Hospital, Okada.

4. Department of Medical Laboratory science, University of Benin, Nigeria.

\begin{abstract}
This study examines teachers' perception of punishment as control methods for secondary school students in Oredo Local Government Area of Edo State the rate of indiscipline amongst students in our secondary schools has assumed an alarming magnitude which has occasioned or elicited various control methods as perceived by teachers. The research design adopted was descriptive. The finding of the study revealed that, there is no significant difference between the professional training of a teacher in the perception on the enforcement of punishment by the teacher due to sex. Data was analyzed using descriptive, frequency count and t-test of mean difference statistics with SPSS. The study recommends that opportunities should be made available for both serving teachers and principals to attend in service training programmes, seminars and workshops on the control of students' behaviour and punishment. At every level in the course of training a teacher should have some aspects of the legal implication of teachers' actions and behaviour should be taught in order to minimize the rate of litigation by parents and students against school authorities.

Keywords: Punishment; indiscipline; Teachers; Litigation; Parents.
\end{abstract}

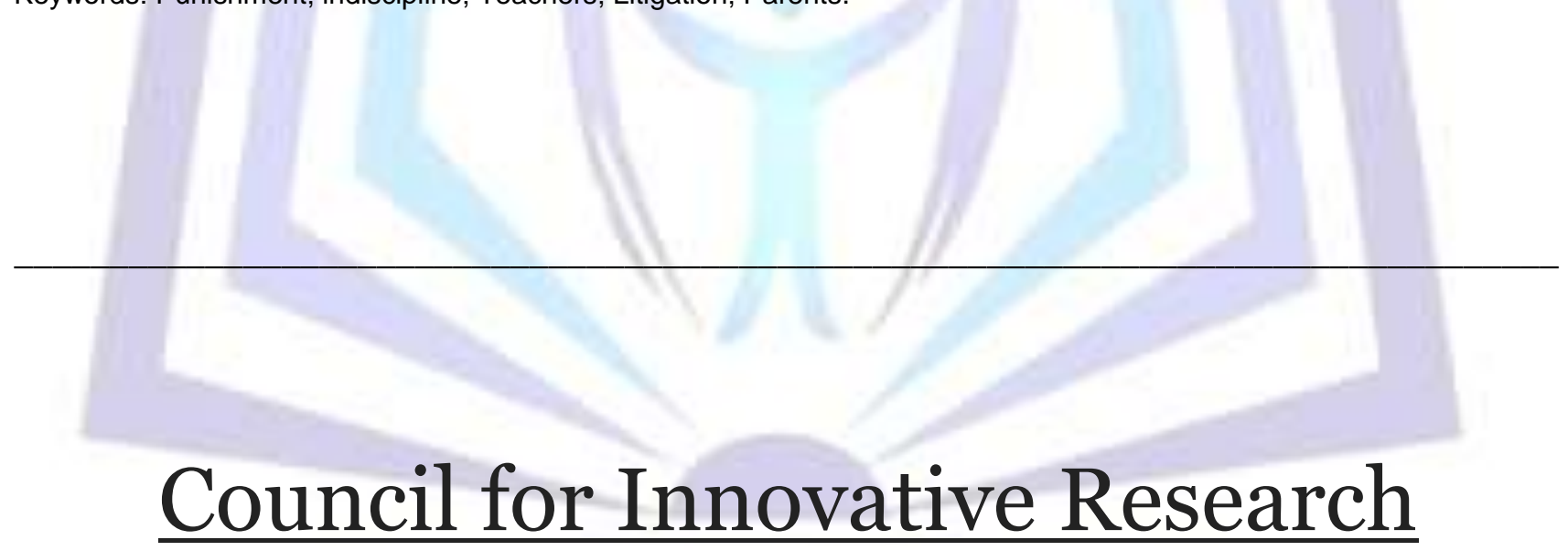

Peer Review Research Publishing System

Journal of Social Science Research

Vol.3, No.2

editor@jssronline.com

www.cirworld.com, member.cirworld.com

\section{INTRODUCTION}


School discipline is defined as school policies and action taken by school personnel to prevent students from unwanted behaviors, primarily focusing on school code of conduct, suspension from school, corporate punishment and teacher's methods of managing students' actions in class (1). It is widely believed that discipline is required for students in order for them to be successful in education, especially during the compulsory education period. Discipline is a branch of knowledge training that develops self control, character, efficiency and strict control to enforce obedience (2).

Eggleton defines discipline as a training which corrects molds or perfects the mental faculties to correct poor behaviors. However, discipline does not necessarily have to involve corporal punishment. (3)

Throughout the history of education, the most common means of maintaining discipline in school was corporal punishment. Corporal punishment refers to intentional application of physical pain as a method of changing behaviour. It includes a wide variety of methods such as hitting, slapping, punching, kicking, pinching, shaking, choking, use of various objects (Wooden, paddles, belts, electric, pins), painful body postures, use of electric shock, and use of excessive exercise drill or prevention of urine or stool elimination. When a child is in school, the teacher is expected to act as a substitute parent, with many forms of parental discipline or rewards open to them. This often meant that students were commonly chastised with the birch, cane, paddle or yardstick if they did something wrong. Corporal punishment in school has now disappeared from most western countries, including all European countries. Thirty U.S. states have banned it; the others (mostly in the south) have not. Canning is still used to a significant (though declining) degree in some public schools in Alabama, Arkanas, Tennessee and Texas. Official corporal punishment often by canning, remain common place in school in some Asian, African and Caribbean countries. Most mainstream school in most other countries retains punishment for misbehavior, but is usually takes non corporal forms such as detention and suspension (4). The incidence of indiscipline in secondary school has assumed unimaginable proportion without any conscious effort of the government to meet up to the challenge at hand.

\section{Limitation of the Study}

This study is limited to three schools in Oredo Local Government Area of Edo State, but it will be of immense value to teachers and principals of schools in the country.

\section{Population of the study}

A total of 820 secondary school teachers are in the government secondary schools in Oredo. The population of this study comprises of secondary school teachers in selected three (3) schools in Oredo Local Government Area of Edo State. A total of 60 secondary school teachers constituted the population. The stratified random sampling technique ensured that at least sixty five percent $65 \%$ of the teachers in each of the schools were selected. This list of schools is Oba Akenzua College, Ihogbe College and Idia College in Oredo Local Government area of Edo State.

\section{Data Analysis}

Data was analyzed using one way analysis of variance (ANOVA) and Turkey - Kramer Multiple comparison test using SPSS - 18.0 statistical program. P values $<0.05$ were considered significant.

\section{Results}

Table 4.1 data for comparing difference between professional training of a teacher in the perception on the enforcement of punishment.

\begin{tabular}{|l|l|l|l|l|l|l|l|}
\hline Qualification & N & Mean & Std. Deviation & T & Df & $\begin{array}{l}\text { Sig. } \\
\text { tailed })\end{array}$ & Remark \\
\hline $\begin{array}{l}\text { NCE } \\
\text { Single }\end{array}$ & 19 & 52.2105 & $\begin{array}{l}9.02207 \\
12.56879\end{array}$ & 0.549 & 58 & 0.585 & Accepted \\
\hline
\end{tabular}

\section{Sign at 0.05 (2-tailed)}

From the t-calculated values obtained and presented in table 4.1 above, it was observed that the $t$-calculated value of 0.55 at 58 degree of freedom is less than the $p$-value of 0.59 . This means that there is no significant difference between the professional training of a teacher in the perception on the enforcement of punishment.

Table 4.2 Data for comparing difference between the knowledge of the law of public education of teacher in the perception on the enforcement of punishment.

\begin{tabular}{|c|c|c|c|c|c|c|c|}
\hline Level & $\mathrm{N}$ & Mean & $\begin{array}{l}\text { Std. } \\
\text { Deviation }\end{array}$ & $\mathrm{T}$ & Df & $\begin{array}{l}\text { Sig. } \\
\text { tailed) }\end{array}$ & Remark \\
\hline $\begin{array}{l}\text { Knowledge of } \\
\text { educational law without } \\
\text { knowledge }\end{array}$ & 42 & $\begin{array}{l}52.47548 \\
56.1667\end{array}$ & $\begin{array}{r}10.72548 \\
13.34277\end{array}$ & -1.134 & 58 & 0.262 & Rejected \\
\hline
\end{tabular}

Sign at 0.05 (2-tailed)

From the t-calculated values obtained and presented in 4.2 above, it was observed that the t-calculated value of -1.13 at 58 degree of freedom is higher than the $p$-value of 0.26 . Thus, there is significance difference in the knowledge of the law of public education of teachers. 
Table 4.3 Data for comparing difference between the teaching experiences of teachers in the perception on the enforcement of punishment.

\begin{tabular}{|l|l|l|l|l|l|l|l|}
\hline Teaching & $\mathrm{N}$ & Mean & Std. Deviation & $\mathrm{T}$ & Df & $\begin{array}{l}\text { Sig. } \\
\text { tailed })\end{array}$ & $\begin{array}{l}\text { Remark } \\
\text { Experienced }\end{array}$ Non Experienced \\
\hline
\end{tabular}

Sign at 0.05 (2-tailed)

From the t-calculated values obtained and presented in 4.3 above, it was observed that the t-calculated value of 0.103 at 58 degree of freedom is less than the $p$-value of 0.92 . This means that there is no significant difference between the teaching experiences of teachers in the perception on the enforcement of punishment.

Table 4.4: Data for comparing difference between the perceptions on the enforcement of punishment by the teacher due to sex.

\begin{tabular}{|l|l|l|l|l|l|l|l|}
\hline Sex & N & Mean & $\begin{array}{l}\text { Std. } \\
\text { Deviation }\end{array}$ & T & Df & $\begin{array}{l}\text { Sig. } \\
\text { tailed })\end{array}$ & Remark \\
\hline Male & 46 & 54.0652 & $\begin{array}{l}12.05064 \\
6.73028\end{array}$ & -0.65 & 58 & .948 & Accepted \\
Female & 14 & 54.2857 & 648 & \\
\hline
\end{tabular}

Sign at 0.05 (2 tailed).

From the t-calculated values obtained and presented in 4.4 above, it was observed that the t-calculated value of 0.65 at 58 degree of freedom is less than the $p$-value of 0.95 . Thus, there is no significant difference between in the perception on the enforcement of punishment by the teachers due to sex.

\section{Discussion}

The findings of the study revealed that there is no significant difference between professional training of a teacher in the perception on the enforcement of punishment. This is in line with these finding. The teacher's position as Loco parents (substitute parents while in school) carries special privileges and responsibilities. However, such a teacher is only legally immune, as long as the teacher is acting within the scope of his duties. (4)

The study also revealed that there is significant difference between the knowledge of the law of public education of teachers in the perception on the enforcement of punishment. This finding is in line with the study. School discipline is defined as school policies and action taken by school personnel to prevent students from unwanted behaviors, primarily focusing on school codes of conduct, suspension from school corporal punishment are teacher's method of managing student's action in class. (1)

It also revealed that there is no significant difference between the teaching experiences of teacher in the perception on the enforcement of punishment. This finding is in line with these studies. It is necessary that the respective authorities exercise some form of control so that the goal of the school can be achieved. Effective control by the school can be achieved by the formulation of a set of roles to guide the students in what they are expected to do or not to do $(5,6,7)$. It is generally accepted in Nigeria School System that whenever disruptive behavior severely threatens the physical or emotional well being of the teacher or other children in the class, the disruptive child or student should be removed from the classroom, in suspending the disruptive student from the class, other student of similar inherent behavior will lean to be well behave $(8,9,10)$.

There is no significant difference between in the perception on the enforcement of punishment by the teachers due to sex. This is accordance with the study. The orientation of the perception of teachers could perhaps be traced to the traditional beliefs and expectations of the society (10). Naturally, female teachers are known to react in a more subtle manner to offences committed by students and are therefore expected to exhibit a more favorable attitude. The difference again can be traced probably to the fact that both categories of teachers have no knowledge of the law of education and therefore the difference in their sexes would be no significant.

\section{CONCLUSION}

Although most of the teachers had been equipped with enough knowledge in the course of their training, to influence their level of perception towards students control practices, most of them are still unaware of the legal implication of their actions. The teaching experience of a teacher did not however in any way influence his perception of students control behaviour. The sex of the teacher also did not however stand a determinant factor in the perception of punishment control method of students. Further research should be carried out in other Local Government Areas of Edo state. 


\section{ISSN:2321-1098}

\section{REFERENCES}

[1] Cameron, M. (2006). Managing School discipline and implication for school social workers. National Association of Social Workers 28 (4) $219-228$.

[2] Gordon, T. (1981) Crippling our children with discipline journal of Education. 163(3) 228 - 243. http://www.san.beck.org/punishmentalternatives.html.

[3] Eggleton, T. (2001). Discipline in the School. Eric Digest 1-13 (E0451554)

[4] Gershoff, E.T. (2002). Corporal punishment by parents and associated child behaviours and experiences. Psychological Bulletin 128: 539 - 579

[5] Peters, R.S. (1966). Ethnics and Education. Pp.267 - 268. JSTOR 3120772

[6] Jenson, W.R., Reavis, H.K. and Rhode, G. (1998). The tough kid Longmont Colorado. Sopris West. 33 (4) $1-6$

[7] Skinner, B.F. (1938). The behaviour of organisms. New York: Appleton - Century - Crofts.

[8] McAnany, P.O. (2010) Punishment online Grolier Multimedia Encyclopedia http://plato.standford.edu/entries/punishment/\#2

[9] Hugo, A.B. (2010). Punishment, crime and state. Stanford encyclopedia of philosophy http://plato.standford.edu/entries/legal-punishment/\#puncrista.

[10] Clark, J. (2004). Against the corporal punishment of children Cambridge journal of Education 34(3) 363 - 371 